\title{
POTENTIALITIES AND RISKS OF BIOCHEMICAL EDUCATIONAL RESEARCH VIA INTERNET
}

\author{
M.C. Gomes, R.M. Lima, J. Xavier-Filho, K.V.S. Fernandes
}

UENF Darcy Ribeiro - CBB - LQFPP

The internet is more and more present in worldwide education. There are innumerable projects that stimulate its usage for aiding the teaching-learning process. This new trend modifies the reality of the whole school. However, many copies of identical information are found in several sites: graphs, figures, texts, links and even errors. The aim of this work is to analyse the biochemical issues photosynthesis and cellular respiration available in web pages, taking into account contents quality, trustworthiness and effectiveness. Firstly, 6th secondary level students were inquired by a questionnaire on their use of internet resources. More than 80 percent of them were regular users. The result confirms the already known potential of internet in education. Fourteen sites were analysed regarding to contents, presence of bibliographical references, authorship, titles of responsibles and adequacy to the target public. In relation to contents, presence of conceptual errors, illustrations and other stimulant elements were analysed. None of the sites presented biblioghraphic references; less than half divulged responsible names and their graduation. The great majority do not mention intended public target. In general, the sites did not contained grave conceptual errors, except for two that mention estoma instead estroma, cilica/acilica phosphorylation (for cyclic and acyclic), grama (for grana) and place oxygen as essential for anaerobic respiration. However, one of these sites was the only one that mentioned enzymes and regulation steps of cellular respiration. Half of the sites presented identical texts and figures. None used livened up resources. The majority showed contents as virtual versions of printed books. Illustrations did not present necessary legends. None of the analysed sites, thus, was considered excellent. Trustworthiness is also questionable as much of the contents arte clearly copies of other pages, recurrent even on the errors. Our data strengthen the need for rigorous evaluation concerning of scholarly research of biochemical themes on the web. Supported by: UENF 